\title{
Spotted fever group rickettsiae in ticks of migratory birds in Romania
}

Ioan-Daniel Mărcuțan, Zsuzsa Kalmár, Angela Monica Ionică, Gianluca D’Amico, Andrei Daniel Mihalca, Cozma Vasile and Attila D. Sándor

\begin{abstract}
Background: Birds are important hosts and dispersers of parasitic arthropods and vector-borne zoonotic pathogens. Particularly migratory species may carry these parasites over long distances in short time periods. Migratory hotspots present ideal conditions to get a snapshot of parasite and pathogen diversity of birds migrating between continents. The aim of this study was to investigate the presence and diversity of Rickettsia spp. in ticks collected from birds at a migratory hot-spot in the Danube Delta, Romania, eastern Europe.
\end{abstract}

Methods: DNA was extracted from ticks that were collected from migratory birds in the Danube Delta during migratory seasons in 2011-2012. Two $360 \mathrm{bp}$ fragments of the 165 ribosomal RNA gene and a $381 \mathrm{bp}$ fragment Gene gltA were PCR amplified and analyzed by sequence analysis (performed at Macrogen Europe, Amsterdam, The Netherlands). Nucleotide sequences were compared to reference sequences available in the GenBank database, using Basic Local Alignment Search Tool.

Results: Four hundred ticks of four different species were found on 11 bird species. The prevalence of Rickettsia spp. infection was $14 \%$ (56/400, Cl: 11.7-29.1), with significantly more nymphs hosting rickettsial infection compared to larvae (48 vs 7; $P<0.001$ ). Significantly more ticks in nymphal stage were hosting Rickettsia spp. infection in spring, than in autumn. Four different genospecies were found: $R$. monacensis (29 ticks), R. helvetica (13), R. massiliae (3) and R. slovaca (2). The seasonal distribution of different Rickettsia spp. was heterogeneous; with most of the $R$. monacensis-infected ticks were found in spring, while more $R$. helvetica were found in autumn than spring. $R$. massiliae was found only in autumn and $R$. slovaca was found only in spring.

Conclusion: This study has shown that birds migrating through eastern Europe may carry ticks infected with a high diversity of rickettsial pathogens, with four Rickettsia spp. recorded. Migratory direction was important for pathogen burden, with seasonal differences in the occurrence of individual Rickettsia species. Here we report the first individual records of different Rickettsia spp. in H. concinna (R. monacensis), I. arboricola (R. helvetica, R. massiliae) and I. redikorzevi ( $R$. helvetica) and also the first geographical record of occurrence of R. massiliae in Romania, representing the easternmost observation on the continent.

Keywords: Migratory birds, Ticks, Rickettsiae, Eastern Europe

\footnotetext{
* Correspondence: attila.sandor@usamvcluj.ro

Department of Parasitology and Parasitic Diseases, Faculty of Veterinary

Medicine, University of Agricultural Sciences and Veterinary Medicine, Calea

Mănăştur 3-5, Cluj Napoca, Romania
} 


\section{Background}

Migratory birds can act as long distance carriers of vectors and pathogens of zoonotic potential [1] and may facilitate their transmission to humans, wildlife and domestic animals through their mobility, potentially exerting a high influence on the geographic distribution of pathogens and vectors [2]. Wild birds are hosts for various ectoparasites including ticks, which are competent vectors for a number of pathogens causing diseases in humans and animals [3]. Birds are known to play an important role in distributing ticks and their associated pathogens within and between continents [4] but they can also act as reservoir hosts in natural foci of disease [5]. In Europe, migratory birds are commonly hosting a number of tick species, with species of the genera Ixodes, Hyalomma, Rhipicephalus and Haemaphysalis most frequently collected [6-8]. Ixodid ticks having a wider host spectrum are important vectors for several agents of human and animal pathogens, including Borrelia spp., Anaplasma spp., Rickettsia spp., Francisella tularensis and Babesia spp. [1]. In Romania, wild birds were found to be parasitized by several tick species, i.e. Ixodes ricinus, I. arboricola, I. redikorzevi, Haemaphysalis concinna, Hyalomma marginatum and Rhipicephalus sanguineus $[9,10]$.

The distribution and frequency of occurrence of certain Rickettsia spp. in ticks is mostly well known in the southern and western part of Europe. However, current knowledge on the diversity of Rickettsia spp. in eastern Europe is almost absent [11]. There are only two studies in Romania detailing the occurrence of Rickettsia spp. group, with [12] demonstrating the presence of $R$. conorii in humans, based on serology, and [13] presenting details on four Rickettsia species in questing and engorged ticks collected from mammalian hosts.

There are two major bird migratory routes in eastern Europe, connecting the north-eastern part of the continent, as well western Siberia to the Mediterranean region and these two join into the Eastern Mediterranean Flyway on the territory of Romania (in the Danube Delta). This region is one of the most important migratory stop-over sites in Europe, with more than 300 species of migratory birds being recorded in most years. Not only the diversity, but also the numbers passing and stopping-over is high, with an estimated two million birds using the diverse habitats of the region twice a year [14]. In addition, 15 tick species were recorded in this area $[9,15]$. Thus, the region provides a unique setting to assess the importance of birds in the cycling of Spotted Fever Group Rickettsia (SFG Rickettsia). There are no data on rickettsial infections of birds or their ticks from Romania. The aim of this study was to investigate the presence of Rickettsia spp. in ticks collected from birds at a migratory hotspot in the Danube Delta.

\section{Methods}

The ticks assessed in this study were collected from the Danube Delta, south-east Romania. Here, passerines were captured during the migratory seasons (spring and autumn), in the years 2011 and 2012. The birds were captured with the use of ornithological mistnets (five shelf type, $12 \mathrm{~m}$ long, Ecotone Inc., Poland) erected in different habitats around the ornithological field laboratory, located at Grindul Lupilor, the Danube Delta Biosphere Reserve, Constanța county, Romania $(44.695848 \mathrm{~N}, 28.939243 \mathrm{E})$. The fauna of the area is rich in breeding water birds and passerines breeding in reed-beds, with high numbers of migrant passerines using the area as short-time stop-over location in both migratory seasons [10]. The trapping lasted for one week in each season and occurred in April and October in both years, targeting the migration peak of small to medium sized passerines in the region (for further details see [10]). Ticks were collected from the head and body of birds with fine tweezers and preserved in $96 \%$ ethanol using a separate vial for each bird. Ticks were identified using standard morphological keys $[16,17]$ under a stereomicroscope.

For studying the seasonal distribution of ticks and the hosted pathogens, the two trapping seasons in any given year (spring and autumn) were considered separately. The bird species were grouped according to their status in the region: migrants (occurring for short periods lasting from a few days to a few weeks in spring and/or autumn) and breeding birds (either migratory or resident, spending the boreal summer in the region).

\section{DNA extraction and PCR}

DNA extraction was performed using a commercial DNA extraction kit (DNAEasyBlood \& Tissue Kit, QIAGEN, Hilden, Germany) according to the manufacturer's recommendations. The quantity and purity of DNA were assessed using spectrophotometer analyses (NanoDropTechnologies model ND-1000 Inc., Wilmington, DE, USA). Briefly, each tick was submitted to DNA extraction and to polymerase chain reaction (PCR) using $10 \mathrm{pmol} / \mu \mathrm{l}$ from each primer (forward: 5' -AAC GCT ATC GGT ATG CTT AAC A-3', reverse: 5' -ACT CAC TCG GTA TTG CTG GA-3') to amplify a $360 \mathrm{bp}$ fragment of the $16 \mathrm{~S}$ ribosomal RNA gene using $2 \times$ Green Master Mix (RovalabGmBH, Teltow, Germany) and for Gene gltA, 381 bp fragment (Primers Rsfg877: 5'-GGG GGC CTG CTC ACG GCG G-3' and Rsfg1258: 5' -ATT GCA AAA AGT ACA GTG AAC A-3'). The PCR reaction was performed according to a previously described protocol [18]. For quality control of the reactions, positive and negative controls were included: for positive control we used Rickettsia DNA previously confirmed by sequencing, while negative control was assured using tap-water instead of DNA. In addition 
amplicons were visualized by electrophoresis in $1.5 \%$ agarose gel stained with SYBR ${ }^{\circ}$ Safe DNA gel stain (Invitrogen, Carlsbad, CA, USA).

\section{DNA sequencing}

PCR products were purified from gel using QIAquick PCR purification kit (QIAGEN, Hilden, Germany) and analyzed by sequence analysis (performed at Macrogen Europe, Amsterdam, The Netherlands). Nucleotide sequences were compared to reference sequences available in the GenBank ${ }^{\mathrm{TM}}$, using Basic Local Alignment Search Tool (BLAST) analysis.

\section{Statistical analysis}

Exact confidence intervals (CIs) for the prevalence rates at the $95 \%$ level were calculated using the software Quantitative Parasitology 3.0 [19]. Sample prevalence data were analyzed using Fisher's exact test. Differences were considered significant when $P<0.05$.

\section{Ethical approval}

The study was carried out according to the national wildlife welfare regulations (OUG57/2007). Licence for bird ringing was provided by the Romanian Ornithological Centre (No 23/2002.).

\section{Results}

Four hundred ticks were collected from 95 birds, belonging to 11 species. Four species of ticks were found: Ixodes ricinus, I. arboricola, I. redikorzevi, Haemaphysalis concinna (Table 1). Ixodes ricinus was the most abundant tick, infesting $84.2 \%$ (80/95, CI: 75.4-90.6) of wild birds, mainly as larvae and nymphs. Regarding host preferences, this species also showed the widest host range, parasitizing altogether ten bird species (data not shown).

All ticks were tested for the presence of SFG rickettsiae. Overall 14 \% (56/400, CI: 11.7-29.1) of ticks were infected by Rickettsia spp., with significantly more nymphs hosting rickettsial infection compared to larvae (47 vs 8; $P<0.001)$. The prevalence of Rickettsia spp. infection in larvae was $4.0 \%$ (8/197, CI: 1.7-7.3), in nymphs it was $24.1 \%$ (47/195,

Table 1 Number of Rickettsia spp. - infected ticks collected from birds in the Danube Delta, Romania (total number of analyzed ticks in parentheses)

\begin{tabular}{lllll}
\hline \multirow{2}{*}{ Tick species } & \multicolumn{3}{l}{ Developmental stage } & \\
\cline { 2 - 4 } & Larva & Nymph & Female & Total \\
\hline Haemaphysalis concinna & $1(2)$ & - & - & $1(2)$ \\
Ixodes arboricola & $5(10)$ & $1(15)$ & - & $6(25)$ \\
Ixodes redikorzevi & $1(4)$ & - & - & $1(4)$ \\
Ixodes ricinus & $1(181)$ & $46(180)$ & $1(8)$ & $48(369)$ \\
Total & $8(197)$ & $47(195)$ & $1(8)$ & $56(400)$ \\
\hline
\end{tabular}

CI: 18.9-31.2), while in adult females it was $12.5 \%(1 / 8, \mathrm{CI}$ : 0.6-5.0) (Table 1).

The prevalence of rickettsial infection was $14.4 \%$ (48/ 369, CI: 11.1-18.4) for I. ricinus, and $24.0 \%$ (6/25, CI: 7.2-40.7) for I. arboricola, while from each of the other two tick species, one infected individual was detected (Table 1). Positive samples were yielded by a proportion of $51.8 \%(29 / 56)$ of ticks collected during spring and $48.2 \%(27 / 56)$ collected during autumn. Significantly more ticks in nymphal stage were hosting Rickettsia spp. infection in spring, compared to autumn $(P<0.001)$, while no differences were found among the infection rate of the other development stages. A significantly higher proportion of birds was carrying Rickettsia spp.-infected ticks in spring, than in autumn $(P<0.001)$.

\section{DNA sequencing}

The 56 positive samples were sequenced (Table 2) and nucleotide sequences were compared to those available in GenBank ${ }^{\mathrm{TM}}$. BLAST analysis of these sequences showed $100 \%$ similarity with $R$. monacensis (accession nos LN794217.1 and NR_115686.1), R. helvetica (accession nos KJ740388, KJ577822, L36212.1 and DQ910785), $R$. slovaca (accession no. L36224.1) and $99 \%$ with $R$. massiliae (accession no. NR_074486), respectively. Only those samples, where similarity of $99 \%$ or above was achieved (47/56) were assigned to a particular species [20]. Thus, the rickettsiae were identified as follows: $R$. monacensis in 29 ticks, $R$. helvetica in 13 ticks, $R$. massiliae in three ticks and $R$. slovaca in two ticks. No coinfection was detected in any of the sampled ticks. There were several cases where bird hosting multiple ticks, were carrying ticks with more than one rickettsial agent (e.g. individual ticks with one Rickettsia spp. each). We submitted the nucleotide sequences for all four Rickettsia species identified to GenBank ${ }^{\mathrm{Tm}}$. The nucleotide sequence accession numbers are as follows: KR906075 for $R$. helvetica, KR906079 for $R$. monacensis, KR906080 for $R$. slovaca and KR906076 for R. massiliae.

Table 2 The distribution of different Rickettsia spp. among ticks collected from birds in the Danube Delta, Romania (no co-infection was noted)

\begin{tabular}{|c|c|c|c|c|c|}
\hline \multirow[b]{2}{*}{ Tick species } & \multirow[b]{2}{*}{$\begin{array}{l}\text { No. of } \\
\text { ticks }\end{array}$} & \multicolumn{4}{|c|}{ Spotted Fever Rickettsiae } \\
\hline & & $\begin{array}{l}R . \\
\text { helvetica }\end{array}$ & $\begin{array}{l}R . \\
\text { massiliae }\end{array}$ & $\begin{array}{l}R . \\
\text { monacensis }\end{array}$ & $\begin{array}{l}R . \\
\text { slovaca }\end{array}$ \\
\hline $\begin{array}{l}\text { Haemaphysalis } \\
\text { concinna }\end{array}$ & 2 & - & - & 1 & - \\
\hline Ixodes arboricola & 25 & 4 & 1 & 1 & - \\
\hline Ixodes redikorzevi & 4 & 1 & - & - & - \\
\hline Ixodes ricinus & 369 & 8 & 2 & 27 & 2 \\
\hline Total & 400 & 13 & 3 & 29 & 2 \\
\hline
\end{tabular}


The seasonal distribution of different Rickettsia spp. was heterogeneous, with some species occurring both in spring and in autumn, while some occurred only in one season. Most of the $R$. monacensis - infected ticks were found in spring (75\% of occurrences), while more $R$. helvetica-infected nymphs were found in autumn (84\% of occurrences) than in spring. Rickettsia slovaca was found only in spring while $R$. massiliae was found only in autumn.

There was no statistically significant difference between the prevalence of Rickettsia spp. in ticks of migratory $v s$ breeding bird species, although migratory birds were carrying ticks with more diverse Rickettsia species (4 vs 1 Rickettsia spp., with only $R$. helvetica found in ticks of breeding birds, Table 3). A total of six bird species was hosting ticks infected by rickettsial pathogens, with one species, the common blackbird (Turdus merula) carrying ticks infected with three species of Rickettsia spp. in spring migration and two species of Rickettsia spp. in autumn, while the song thrush (Turdus philomelos) was recorded to carry ticks with three Rickettsia spp. in autumn (Table 3). Generally, ticks hosted by birds with more than one tick tended to be infested by more Rickettsia species, with higher rickettsial prevalence associated to bird species carrying more ticks. However, we found no correlation between the prevalence of tick infestation and prevalence or number of Rickettsial species in ticks. In the meantime, the intensity of tick infestation (mean number of ticks on parasitized birds) was a good indicator of rickettsial species diversity of ticks hosted by individual bird species (Table 3, $P<0.01$ ).

\section{Discussion}

This is the first study in Romania showing that wild birds may contribute to the dispersion of Rickettsia spp. and that birds have an important role in the natural cycle of Rickettsia species associated with SFG rickettsioses in humans. Moreover, this is the first report and direct evidence of the presence of $R$. massiliae in Romania in ticks and also it represents the easternmost occurrence of this rickettsial agent in Europe [11]. SFG rickettsiae were already detected in more than 32 European countries, with most studies concentrating on questing ticks, while their occurrence in ticks of wildlife and especially their reservoirs are mostly unknown [11]. There are only a few studies which targeted ticks of migratory birds and their results suggested that birds may play an important role in the dispersion and maintenance of Rickettsia spp. in nature [7, 8, 21-24]. Moreover, studies suggest that birds may carry diverse tick communities and the associated rickettsial pathogen distribution is not uniform. In the present study, the majority of ticks was $I$. ricinus and represented $85.7 \%(48 / 56)$ of all the infected ticks hosting four different rickettsial pathogens ( $R$. helvetica, $R$. massiliae, $R$. monacensis and $R$. slovaca). Three different

Table 3 Species and numbers of individuals of birds hosting ticks, with prevalences of SHG rickettsiae and details on life history status (migrant/breeding), migratory season (spring/autumn) and Rickettsia spp. harbored

\begin{tabular}{|c|c|c|c|c|c|c|c|}
\hline \multirow{3}{*}{ Host species } & \multicolumn{3}{|l|}{ Tick presence } & \multicolumn{4}{|c|}{ Rickettsia spp. presence } \\
\hline & \multirow{2}{*}{$\begin{array}{l}\text { No. of } \\
\text { birds examined }\end{array}$} & \multirow{2}{*}{$\begin{array}{l}\text { Prevalence } \\
(\%)\end{array}$} & \multirow[t]{2}{*}{ Intensity } & \multicolumn{2}{|l|}{ Spring } & \multicolumn{2}{|l|}{ Autumn } \\
\hline & & & & $\begin{array}{l}\text { Prevalence } \\
\text { (\%) }\end{array}$ & Rickettsia species & $\begin{array}{l}\text { Prevalence } \\
\text { (\%) }\end{array}$ & Rickettsia species \\
\hline $\begin{array}{l}\text { Cyanistes } \\
\text { caeruleus }\end{array}$ & 29 & 6.90 & 1 & & & & \\
\hline $\begin{array}{l}\text { Emberiza } \\
\text { schoeniclus }\end{array}$ & 11 & 9.10 & 1 & & & & \\
\hline Erithacus rubecula & 352 & 8.20 & 5.9 & 20.0 & monacensis & 3.1 & monacensis, helvetica \\
\hline $\begin{array}{l}\text { Ficedula } \\
\text { hypoleuca }\end{array}$ & 10 & 10.00 & 2 & & & & \\
\hline Panurus biarmicus & 306 & 0.06 & 1 & & & 100 & helvetica \\
\hline Parus major & 16 & 50 & 1.9 & & & 8.3 & Unidentified Rickettsia spp. \\
\hline $\begin{array}{l}\text { Phylloscopus } \\
\text { collybita }\end{array}$ & 96 & 0.10 & 1 & & & 100 & Unidentified Rickettsia spp. \\
\hline Regulus regulus & 47 & 4.20 & 1 & & & & \\
\hline Remiz pendulinus & 5 & 20.00 & 1 & & & & \\
\hline Turdus merula & 140 & 30.70 & 3.4 & 32.5 & $\begin{array}{l}\text { monacensis, helvetica, } \\
\text { slovaca }\end{array}$ & 14.2 & monacensis, helvetica \\
\hline Turdus philomelos & 91 & 6.60 & 9.3 & 50.0 & $\begin{array}{l}\text { Unidentified Rickettsia } \\
\text { spp. }\end{array}$ & 16.9 & $\begin{array}{l}\text { monacensis, helvetica, } \\
\text { massiliae }\end{array}$ \\
\hline
\end{tabular}


Rickettsia spp. were detected in I. arboricola ticks, with two of them unrecorded to date ( $R$. helvetica and $R$. massiliae). While former studies regularly detected Rickettsia spp. in I. arboricola collected from migratory birds, these belonged to $R$. monacensis and 'Candidatus Rickettsia vini' [25-27]. Ixodes redikorzevi has a Palaearctic distribution, being primarily a small mammal parasite, with sporadic occurrences on humans $[28,29]$. It is rarely recorded from birds [10] and the present study is the first to show its potential role in the maintenance and circulation of $R$. helvetica in nature. Although numerous studies report the presence of $H$. concinna in wild birds $[7,26,30]$, with at least three different species of Rickettsia (R. helvetica, $R$. heilongjiangensis and $R$. sibirica) already identified in $H$. concinna ticks [7, 31, 32]; to the best of our knowledge this is the first detection of $R$. monacensis in this tick species.

Rickettsia helvetica was identified for the first time in 1979 in Switzerland from I. ricinus. Because transstadial and transovarial transmission of this rickettsia has been demonstrated in I. ricinus, this tick represents both a potential vector and a natural reservoir of $R$. helvetica [33]. This bacterium has already been detected in 24 European countries [11]. For approximately 20 years, $R$. helvetica was considered non-pathogenic; however, in 1999, it was found responsible for causing fatal perimyocarditis in several patients in Sweden [34], while recently it was found causing neuritis and Bell's palsy [35]. Rickettsia helvetica was formerly found to be harbored by ticks collected from birds, with prevalence values ranging from $0.5 \%$ in Germany [22] to $10.3 \%$ in Russia [23], or as high as $51.4 \%$ in Hungary [7]. In the Danube Delta, its prevalence was low in I. ricinus (1.9\%), comparable to Germany [22]. The seasonal distribution of $R$. helvetica in the current study is similar to the situation found [21] in Sweden, where autumn migrating passerines were carrying most ticks infected with this pathogen. The high prevalence of $R$. helvetica found in I. arboricola (16\%) may be an indication of reservoir competence for the song thrush. One individual belonging to this bird species harbored 32 ticks (27 I. ricinus nymphs and five I. arboricola larvae), of which one I. ricinus and four I. arboricola were infected by this pathogen. Even if the possibility of co-feeding transmission between the two tick species cannot be ruled out, this is however the first detection of R. helvetica in $I$. arboricola.

Rickettsia monacensis was detected for the first time in Germany in I. ricinus, it is a SFG Rickettsia which is distributed all over Europe [36]. This bacterium causes a zoonotic disease, characterized by acute fever (present in most cases), accompanied by chills, headache, photophobia, arthralgia, muscular pain, etc. [11]. The prevalence of $R$. monacensis in ticks varied between low $(<1 \%$, Mediterranean region, [8]) and very high (42.8\% in
Germany, [22]). It is associated primarily with I. ricinus [36]. In the Danube Delta this pathogen was detected in three different tick species, with a prevalence of $2.7 \%$ in I. ricinus. Similar prevalence was recorded in Russia [23] and Switzerland [24], while the seasonal distribution was similar (mostly in spring) on the Baltic Sea Island of Greifswalder Oie, in Germany [22]. Similarly, birds migrating through Ottenby, Sweden were carrying $R$. monacensis - infected ticks only in spring [21]. The common blackbird (Turdus merula) seems to be an important species for this pathogen, as most infected ticks (and also tick species) were found on this species of bird. $R$. monacensis was found in nine out of 14 nymphs harbored by an individual common blackbird, suggesting the reservoir competence for this species. This bird species also seem to be the most common bird-host for ticks carrying $R$. monacensis in most studies to date [7, $21,24,30]$.

Rickettsia slovaca was described for the first time in 1968, from Dermacentor marginatus in the former Czechoslovakia [37]. Human infections with this agent were recorded in France, Slovakia, Italy, Germany, Hungary, Spain and Poland [37]. Rickettsia slovaca has been found in $D$. marginatus and $D$. reticulatus ticks in Europe, with only these tick species being considered important vectors for this pathogen [38]. Its presence in ticks carried by birds was not recorded previously. This rickettsia is known to cause SENLAT syndrome in humans, with scalp eschar and neck lymphadenopathy commonly occurring in patients [33]. It was already recorded in Romania from free ticks [13], and recently was identified serologically from interned patients with symptoms of SENLAT syndrome in Bucharest [39].

Rickettsia massiliae was isolated from Rhipicephalus sanguineus, Rh. turanicus, Rh. pusillus, Rh. bursa and I. ricinus in eight European countries, including five islands: Sardinia and Sicily (Italy), the Canary Islands (Spain), Kephalonia (Greece), and Cyprus [11]. Rickettsia massiliaeinfected ticks were collected from a wide range of animal hosts, including birds $[6,40]$. It has a southern European and African distribution, with most records originating from the Mediterranean region in our continent [11]. Here we report its detection in two different tick species (I. ricinus and I. arboricola), with the easternmost occurrence on the European continent. Two occurrences were identified in ticks carried by two different song thrushes and the third one carried by a common blackbird, all cases recorded in autumn. Rickettsia massiliae causes a typical spotted fever disease (with febrile sensation, tick eschar with purpuric rash, asthenia, headache and, sometimes, face edema [33]. Although this rickettsial agent was not yet identified in Romanian ticks, its presence was recently recorded (and proved serologically) in six different patients interned with SENLAT syndrome [39]. 
In the current study, infections with several different tick-borne pathogens were determined for ticks carried by birds for the first time in Romania, highlighting the importance of migratory birds in the dispersion of SFG rickettsiae. Here we report the first individual records of different Rickettsia spp. in $H$. concinna ( $R$. monacensis), $I$. arboricola ( $R$. helvetica, $R$. massiliae) and I. redikorzevi ( $R$. helvetica), providing details also on their seasonal distribution. Birds migrating through the Danube Delta carried ticks with a number of four different rickettsial pathogens and migratory orientation and life history determined the rickettsial infection of ticks. Thus, $R$. monacensis and $R$. slovaca were the dominant pathogens in the pre-breeding period, when birds migrated from South and South-West towards North and North-East, while $R$. helvetica and $R$. massiliae were detected from birds in post-breeding migration, when birds travel to South and South-West. As migratory passerines usually have high migratory speed [41], they may easily transfer ticks to long distances, easily passing barriers otherwise insurmountable for ticks. By hosting ticks infected by diverse rickettsial agents, birds may be competent carriers of SFG rickettsiae over large distances or even between continents [21]. A number of studies proved the presence of multiple rickettsial pathogens in ticks of migratory birds $[2,6,19-22,24,26]$, with several locations listed with more than one (up to three) Rickettsia spp. found $[7,8,23,32]$. To the best of our knowledge the Danube Delta is unique in providing records of four different SFG rickettsiae identified in ticks collected from migratory birds. Although the prevalence rates found in this study were low, the high diversity and specific importance of different host species make the birds important as sentinels and also as long distance carriers for rickettsial pathogens.

\section{Conclusion}

This study has shown that birds migrating through eastern Europe may carry ticks infected with a high diversity of rickettsial pathogens, with four Rickettsia spp. recorded. Migratory direction was important for pathogen burden, with seasonal differences in the occurrence of individual Rickettsia species. This is the first record of occurrence of R. massiliae in Romania, representing the easternmost record on the continent.

\section{Competing interests}

The authors declare that they have no competing interests.

\section{Authors' contributions}

Study design by ADS, CV and ADM. Tick collection by ADS, IDM and GDA. IDM, ADS and GDA identified the ticks; IDM, AMI and ZK extracted the DNA and performed the molecular analyses. IDM and ADS wrote the manuscript. ADM and VC supervised parasitological work. All authors read and approved the final version of the manuscript.

\section{Acknowledgments}

We are grateful to ARBDD for issuing the research permits. This research was supported for ADM, ADS and GDA from grant PCE 236/2011. This study was conducted under the frame of the EurNegVec COST Action TD1303. The work of IDM and ZK was financed by POSDRU grant no. 159/1.5/S/136893 grant with the title: "Parteneriat strategic pentru creşterea calității cercetării științifice din universitățile medicale prin acordarea de burse doctorale și postdoctorale - DocMed.Net 2.0".

Received: 24 November 2015 Accepted: 4 May 2016

Published online: 20 May 2016

\section{References}

1. Hasle G. Transport of ixodid ticks and tick-borne pathogens by migratory birds. Front Cell Infect Microbiol. 2013;10:48.

2. Hamer SA, Goldberg TL, Kitron UD, Brawn JD, Anderson TK, Loss SR, et al. Wild birds and urban ecology of ticks and tick-borne pathogens, Chicago, Illinois, USA, 2005-2010. Emerg Infect Dis. 2012;18(10):1589-95.

3. Hoogstraal H, Kaiser MN, Traylor MA, Gaber S, Guindy E. Ticks (Ixodoidea) on birds migrating from Africa to Europe and Asia. Bull World Health Organ. 1961;24:197-212.

4. Olsen B, Jaenson TGT, Bergström S. Prevalence of Borrelia burgdorferi sensu lato-infected ticks on migrating birds. Appl Environ Microbiol. 1995:61:3082-7.

5. Humair PF, Postic D, Wallich R, Gern L. An avian reservoir (Turdus merula) of the Lyme borreliosis spirochaetes. Zentralbl Bakteriol. 1998;287:521-38.

6. Santos-Silva MM, Sousa R, Santos AS, Melo P, Encarnação V, Bacellar F. Ticks parasitizing wild birds in Portugal: detection of Rickettsia aeschlimannii, $R$. helvetica and R. massiliae. Exp Appl Acarol. 2006;39:331-8.

7. Hornok S, Kováts D, Csörgő T, Meli ML, Gönczi E, Hadnagy Z, et al. Birds as potential reservoirs of tick-borne pathogens: first evidence of bacteraemia with Rickettsia helvetica. Parasit Vectors. 2014;7:128.

8. Wallménius $K$, Barboutis $C$, Fransson $T$, Jaenson GTE, Lindgren PE, Nyström F, et al. Spotted fever Rickettsia species in Hyalomma and Ixodes ticks infesting migratory birds in the European Mediterranean area. Parasit Vectors. 2014;7:318

9. Mihalca AD, Dumitrache MO, Magdaș C, Gherman CM, Domşa C, et al. Synopsis of the hard ticks (Acari: Ixodidae) of Romania with update on host associations and geographical distribution. Exp Appl Acarol. 2012;58:183-206.

10. Sándor $A D$, Mărcutan DI, D'Amico G, Gherman CM, Dumitrache MO, Mihalca AD. Do the ticks of birds at an important migratory hotspot reflect the seasonal dynamics of /xodes ricinus at the migration initiation site? A case study in the Danube Delta. PLoS One. 2014;9(2):e89378.

11. Parola P, Paddock CD, Socolovschi C, Labruna MB, Mediannikov O, Kernif T, et al. Update on tick-borne rickettsioses around the world: a geographic approach. Clin Microbiol Rev. 2013;26:657-702.

12. Serban R, Pistol A, Negu M, Cucuiu R. Rickettsia conorii infection in Romania, 2000-2008. Bacteriol Virusol Parazitol Epidemiol. 2009;54:177-83. In Romanian.

13. Ionița M, Mitrea IL, Pfister K, Hamel D, Silaghi C. Molecular evidence for bacterial and protozoan pathogens in hard ticks from Romania. Vet Parasitol. 2013;196:71-6.

14. Hahn S, Bauer S, Liechti F. The natural link between Europe and Africa -2.1 billion birds on migration. Oikos. 2009;118:624-26.

15. Sándor AD, Dumitrache MO, D'amico G, Kiss BJ, Mihalca AD. Rhipicephalus rossicus and not $R$. sanguineus is the dominant tick species of dogs in the wetlands of the Danube Delta, Romania. Vet Parasitol. 2014:204:430-32.

16. Feider Z. Ixodoidea. In: Fauna of the Popular Republic of Romania, vol. 5/2. Bucuresti: Ed. Academiei Republicii Populare Romane; 1965 [in Romanian].

17. Nosek J, Sixl W. Central-European ticks (Ixodoidea). Mitt Abteil Zool Botanik Landesmus Joanneum. 1972;1:61-92.

18. Tijsse-Klasen E, Pandak N, Hengeveld P, Takumi K, Koopmans MP, Sprong H. Ability to cause erythema migrans differs between Borrelia burgdorferi sensu lato isolates. Parasit Vectors. 2013;6:23.

19. Rózsa L, Reiczigel J, Majoros G. Quantifying parasites in samples of hosts. J Parasitol. 2000;86:228-32.

20. Fournier PE, Dumler JS, Greub G, Zhang J, Wu Y, Raoult D. Gene sequencebased criteria for identification of new rickettsia isolates and description of Rickettsia heilongjiangensis sp. nov. J Clin Micribiol. 2003;41:5456-65. 
21. Elfving K, Olsen B, Bergström S, Waldenström J, Lundkvist A, Sjöstedt A, et al. Dissemination of spotted fever rickettsia agents in Europe by migrating birds. PLoS One. 2010;5(1):e8572.

22. Hildebrandt A, Franke J, Meier F, Sachse S, Dorn W, Straube E. The potential role of migratory birds in transmission cycles of Babesia spp., Anaplasma phagocytophilum, and Rickettsia spp. Ticks Tick Borne Dis. 2010;1(2):105-7.

23. Movila A, Reye AL, Dubinina HV, Tolstenkov OO, Toderas I, Hübschen JM, et al. Detection of Babesia Sp. EU1 and members of spotted fever group rickettsiae in ticks collected from migratory birds at Curonian Spit, NorthWestern Russia. Vector Borne Zoonotic Dis. 2011;11:89-91.

24. Lommano E, Dvorák C, Vallotton L, Jenni L, Gern L. Tick-borne pathogens in ticks collected from breeding and migratory birds in Switzerland. Ticks Tick Borne Dis. 2014:5:871-82.

25. Palomar AM, Santibáñez P, Mazuelas D, Roncero L, Santibáñez S, Portillo A, Oteo JA. Role of birds in dispersal of etiologic agents of tick-borne zoonoses, Spain, 2009. Emerg Infect Dis. 2012;18:1188-91.

26. Spitalská E, Literák I, Kocianová E, Taragel'ová V. The importance of Ixodes arboricola in transmission of Rickettsia spp., Anaplasma phagocytophilum, and Borrelia burgdorferi sensu lato in the Czech Republic, Central Europe. Vector Borne Zoonotic Dis. 2011;11:1235-41.

27. Novakova M, Bulkova A, Costa FB, Kristin A, Krist M, Krause F, et al. Molecular characterization of 'Candidatus Rickettsia vini'in Ixodes arboricola from the Czech Republic and Slovakia. Ticks Tick Borne Dis. 2015;6:330-33.

28. Yeruham I, Hadani A, Aroch I, Galker F, Gilor H, Rodrig S. Cases of apparent tick toxicosis in humans and dogs, caused by Ixodes redikorzevi sl. Ann Trop Med Parasitol. 2000;94:413-15.

29. Bursali A, Keskin A, Tekin S. Ticks (Acari: Ixodida) infesting humans in the provinces of Kelkit Valley, a Crimean-Congo Hemorrhagic Fever endemic region in Turkey. Exp Appl Acarol. 2013;59:507-15.

30. Hornok S, Csörgő T, de la Fuente J, Gyuranecz M, Privigyei C, Meli ML, et al. Synanthropic birds associated with high prevalence of tick-borne rickettsiae and with the first detection of Rickettsia aeschlimannii in Hungary. Vector Borne Zoonotic Dis. 2013;13:77-83.

31. Chen M, Fan MY, Bi DZ, Zhang JZ, Huang YP. Detection of Rickettsia sibirica in ticks and small mammals collected in three different regions of China. Acta Virol. 1998;42:61-4.

32. Shpynov S, Fournier PE, Rudakov N, Tarasevich I, Raoult D. Detection of members of the genera Rickettsia, Anaplasma, and Ehrlichia in ticks collected in the Asiatic part of Russia. Ann New York Acad Sci. 2006;1078:378-83.

33. Parola P, Paddock CD, Raoult D. Tick-borne rickettsioses around the world: emerging diseases challenging old concepts. Clin Microbiol Rev. 2005;18:719-56.

34. Nilsson K, Lindquist O, Påhlson C. Association of Rickettsia helvetica with chronic perimyocarditis in sudden cardiac death. Lancet. 1999:354(9185):1169-73.

35. Nilsson K, Wallmenius K, Hartwig S, Norlander T, Påhlson C. Bell's palsy and sudden deafness associated with Rickettsia spp. infection in Sweden. A retrospective and prospective serological survey including PCR findings. European J Neurology. 2014:21:206-14.

36. Oteo JA, Portillo A. Tick-borne rickettsioses in Europe. Ticks Tick Borne Dis. 2012;3:271-8.

37. Parola P, Rovery C, Rolain JM, Brouqui P, Davoust B, Raoult D. Rickettsia slovaca and R. raoultii in tick-borne Rickettsioses. Emerg Infect Dis. 2009:15:1105-8.

38. Martello E, Mannelli A, Ragagli C, Selmi M, Ambrogi C, Grego E, et al. Use of small rodents for the surveillance of agents and vectors of tick-borne zoonoses in the northern Apennines, Italy. Parasit Vector. 2014;7:1.

39. Zaharia M, Popescu CP, Florescu SA, Ceausu E, Raoult D, Parola P, et al. Rickettsia massiliae infection and SENLAT syndrome in Romania. Ticks Tick Borne Dis. 2016; doi:10.1016/j.ttbdis.2016.03.008

40. Socolovschi C, Reynaud P, Kernif T, Raoult D, Parola P. Rickettsiae of spotted fever group, Borrelia valaisiana, and Coxiella burnetii in ticks on passerine birds and mammals from the Camargue in the south of France. Ticks Tick Borne Dis. 2012;3:355-60.

41. Yohannes E, Biebach H, Nikolaus G, Pearson DJ. Migration speeds among eleven species of long-distance migrating passerines across Europe, the desert and eastern Africa. J Avian Biol. 2009:40:126-34.

\section{Submit your next manuscript to BioMed Central and we will help you at every step:}

- We accept pre-submission inquiries

- Our selector tool helps you to find the most relevant journal

- We provide round the clock customer support

- Convenient online submission

- Thorough peer review

- Inclusion in PubMed and all major indexing services

- Maximum visibility for your research

Submit your manuscript at www.biomedcentral.com/submit
Biomed Central 